і значення цієї ситуації і загалом, і компонентів, що до неї входять.

Отже, аналіз категорії «контекст» і феноменів, що стоять за ним, відповідно до феноменології лінгвістики, психолінгвістики, філософії, логіки та методології, психології та педагогіки, дає підставу вважати, що поняття контекст у сучасному науковому просторі вийшло за межі свого традиційного лінгвістичного й психолінгвістичного розуміння та отримало загальнонаукове, зокрема психологопедагогічне, трактування. Дослідження саме педагогічних аспектів поняття контекст $€$ перспективним у наших наступних працях.

\title{
Література
}

1. Вербицкий А. А. Категория «контекст» в психологии и педагогике /

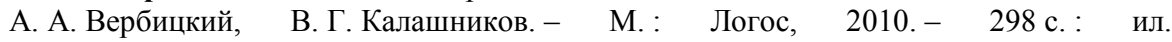
2. Вербицкий А. А. Новая образовательная парадигма и контекстное обучение/ А. А. Вербицкий. - М. : Исслед. центр проблем качества подготовки специалистов, 1999. - 75 с. 3. Дворецкий И. Х. Латинско-русский словарь: более 200000 слов и словосочетаний / И. Х. Дворецкий. - [10-е изд., стер.]. - М. : Рус. яз. Медиа, 2006. 843, [2] с. 4. Ивин А. Словарь по логике / А. Ивин, А. Никифоров. - М. : Гуманит. изд. центр «Владос», 1997. - 384 с. 5. Контексты в образовании субъекта: межвуз. сб. науч. тр. / под ред. А. А. Вербицкого, Н. В. Жуковой. - М. : РИЦ МГОПУ им. М. А. Шолохова, 2005. - 96 с. 6. Леонтьев Д. А. Психология смысла: природа, строение и динамика смысловой реальности / Д. А. Леонтьев. - М.: Смысл, 2003.- 487 с. 7. Никифоров А. Л. Семантическая концепция понимания / А. Л. Никифоров // Загадка человеческого понимания / под ред. А. А. Яковлева. - М., 1991. - С. 72-95. 8. Ребер А. Большой толковый психологический словарь : в 2 т. / Артур Ребер ; пер. с англ. Е. Ю. Чеботарева. - М. : ООО «Изд-во АСТ», 2003. - Т. 1 : А - О. - 591, [1] с.

УДК $378.1 ; 437.6$

Тетяна Ключкович

\section{РОЗВИТОК СИСТЕМИ ПЕДАГОГІЧНОЇ ОСВІТИ В КОНТЕКСТІ РЕФОРМУВАННЯ ВИЩОЇ ШКОЛИ У СЛОВАЦЬКІЙ РЕСПУБЛІЦ}

Ключкович Т. В. Розвиток системи педагогічної освіти в контексті реформування вищої школи у Словацькій Республіці.

У статті розглянуто розвиток словацької вищої школи і педагогічної освіти зокрема в контексті постсоціалістичної модернізації та європейської інтеграції. Зроблено висновок про значні зміни в системі вищої освіти Словаччини, які зорієнтовані на оновлення іiі структур та нормативно-правового забезпечення, модернізацію змісту і методів підготовки фахівців.

Ключові слова: Словацька Республіка, реформа вищої освіти, європейська інтеграція, Болонський процес, педагогічна освіта.

Ключкович Т. В. Развитие системы педагогического образования в контексте реформирования высшей школы в Словацкой Республике.

В статье рассмотрено развитие словацкой высшей школы и педагогического образования в частности в контексте постсоциалистической модернизации и европейской интеграции. Сделан вывод о значительных изменениях в системе высшего образования Словакии, которые 'ориентированы на обновление ее структур и нормативно-правового обеспечения, модернизацию содержания и методов подготовки специалистов.

Ключевые слова: Словацкая Республика, реформа высшего образования, 
европейская интеграция, Болонский процесс, педагогическое образование.

Klyuchkovych T. V. Development of the system of pedagogical education in the context of higher school reform in the Slovak Republic.

The article deals with the development of Slovak higher school and pedagogical education particularly in the context of post-socialist modernization and European integration. The conclusion is made about the significant changes of higher education of Slovakia which are aimed at the refreshment of the branches and regulatory support, contents modernization and methods of the specialists training.

Key words: Slovak Republic, reform of higher education, European integration, the Bologna process, pedagogical education.

Зі здобуттям державної самостійності в 1993 р. перед Словацькою Республікою (далі- СР) поряд 3 необхідністю подальшої розбудови політичних, економічних структур постала потреба модернізації національної системи вищої освіти. Недоліки і кризові явища у функціонуванні словацької вищої школи і педагогічної освіти зокрема стали предметом критики як з боку науковців, так і широкої громадськості. Словацьке суспільство стурбоване такими виявами кризи професії педагога, як-от: недостатня кваліфікованість педагогічних кадрів; соціальна непривабливість професії вчителя; непідготовленість учителів до інформатизації та індивідуалізації освіти; пасивний опір змінам з боку педагогів тощо. [9, с. 9-10].

Проголошений європейський вектор трансформації вищої школи потребував системних організаційних заходів, концептуальних розробок та необхідного законодавчого забезпечення. У процесі інтеграції до європейського освітнього простору вдалося розв'язати багато проблем вищої освіти та підготовки педагогічних кадрів, але чимало недоліків у цій сфері й надалі зберігаються і потребують свого вирішення в майбутньому.

У контексті реалізації Україною євроінтеграційного курсу словацький досвід перетворень у системі вищої освіти $є$ актуальним і заслуговує уваги вітчизняної науки.

Проблематика реформування вищої освіти СР в умовах упровадження Болонського процесу через свою складність і важливість користується підвищеним інтересом словацьких науковців, що відповідно позначається i на ступені іiі дослідження. Сучасний стан, перспективи і проблеми підготовки вчителів у Словаччині досліджують Я. Бургерова, Б. Косова, Н. Крайчова, А. Петрасова, Ш. Порубський, М. Радек та ін. Окремі аспекти розвитку словацької вищої освіти висвітлені в працях вітчизняних науковців: А. Віегорової (педагогічна підготовка викладачів), Т. Кристопчук (вища освіта в порівняльному контексті), В. Старости (педагогічна практика студентів), Ж. Таланової (трициклова вища освіта), Г. Товканець (економічна вища освіта) та ін.

Більшість авторів аналізують базові трансформаційні процеси у вищій школі СР, тоді як розвитку педагогічної освіти приділяється менше уваги. Метою статті $є$ 3'ясування особливостей модернізації системи педагогічної освіти в контексті реформування вищої школи Словацької Республіки, аналіз концептуального та нормативного забезпечення цих змін.

Розвиток системи словацької вищої освіти йшов у тісному зв'язку з іншими перетвореннями в державі, тому складність трансформаційного шляху відобразилася на інтенсивності та результативності реформ в освітній сфері.

У зв'язку з перетвореннями у сфері вищої освіти словацький дослідник Б. Косова 
пропонує виокремлювати три основних етапи в розвитку педагогічної підготовки вчителів: початковий етап трансформації (1990-1996/97рр.), етап концептуалізації та європеїзації (1996/97-2004 рр.), етап упровадження структурованої підготовки вчителів з 2004-2005 pp. [9, с. 23-28].

У контексті постсоціалістичної трансформації після 1989 р., в умовах спільної держави чехів і словаків - Чеської і Словацької федеративної республіки - систему вищої освіти вдалося демократизувати, але глибоких якісних змін здійснено не було. У першій половині 1990-х рр. в Словаччині в контексті деідеологізації вищої освіти виявилися тенденції до т. зв. «депедагогізації» вищої школи, оскільки педагогіка вважалася носієм марксистської ідеології [9, с. 23]. Зокрема, це відобразилося в ліквідації окремих педагогічних курсів, зменшенні кількості та обсягу педагогічних дисциплін у навчальних програмах, скороченні годин педагогічної практики. У сфері педагогічної науки дослідження не тільки не підтримувалися, але й обмежувалися, ліквідовувалися державні дослідницькі педагогічні центри, зокрема Інститут експериментальної педагогіки, Дослідницький педагогічний інститут Словаччини.

Складний політичний контекст діяльності уряду В. Мечіара (1994-1998рр.) відображався на освітній системі, цілі розвитку якої коливалися між відкритістю (європеїзацією) та закритістю (націоналізацією). Системні перетворення у сфері вищої освіти в цей період не відбувалися, здійснювалися тільки часткові зміни на рівні формальної організації та адміністративного управління освітнім процесом.

Інновації в педагогічній сфері виявлялися насамперед на мікрорівні- в діяльності освітніх неурядових організацій, ініціативних груп та педагогічних об'єднань, що розробляли навчальні, дидактичні матеріали різних альтернативних концепцій навчання. Але реформаторські рухи знизу наштовхувалися на бар'єр нерозуміння з боку влади, що призвело до помітної зневіри педагогів та інноваційного руху загалом у реальних можливостях реформ.

Попри т. зв. «застій» у цей період, все-таки варто підкреслити окремі урядові кроки щодо вдосконалення нормативно-правового регулювання педагогічної освіти. У січні 1996 р. Міністерством освіти СР було прийнято Постанову «Про професійну та освітню кваліфікацію педагогічних працівників» [8], яка більш ніж десятиліття була єдиним документом, що нормативно визначав вимоги до кваліфікації педагогічних працівників, їх професійних знань, умінь та навичок. Постанова Міністерства освіти СР від 26 січня 1996 р. нормативно забезпечувала підвищення кваліфікації педагогів [7].

Попри декларативно проголошений європейський вектор трансформації словацької вищої школи, упродовж 1990-х років для якісних змін бракувало системних організаційних заходів, концептуальних розробок та відповідного законодавчого забезпечення.

Реформи намітилися тільки зі зміною політичного керівництва країни. В листопаді 1998 р. у програмній заяві уряду М. Дзурінди розвиток освіти було проголошено пріоритетним напрямком та взято курс на створення цілісної концепції розвитку виховання й освіти на тривалу перспективу [4, с. 28]. Після суспільного обговорення концепції розвитку виховання та освіти (проект «Milenium») в 2001 році уряд схвалив «Національну програму виховання і освіти в Словацькій Республіці» [3], у якій робиться наголос на ключових проблемах і пріоритетах розвитку у сфері національної освіти.

У стратегічному вимірі також важливим було те, що 30 серпня 2000 року урядом Словаччини було ухвалено «Проект концепції подальшого розвитку вищої освіти в Словаччині на 21 століття» [6], у якому зафіксовано стан розвитку вищої освіти, 
встановлено орієнтири й механізми змін, підтверджено необхідність рухатися в напрямку гармонізації словацької вищої освіти із загальноєвропейськими цілями Болонського процесу.

Концептуалізація педагогічної освіти знайшла вияв у появі нових педагогічних та дидактичних ідей щодо підготовки вчителів. У рамках концептуалізації педагогічної освіти розроблялися і нормативно закріплювалися положення щодо особистісно зорієнтованого навчання, посилення практичної підготовки вчителів, оновлення навчальних планів і програм, зміни змісту й обсягу педагогічних, психологічних дисциплін тощо.

У зовнішньополітичній площині важливим імпульсом до європеїзації вищої освіти було підписання Словаччиною в червні 1999 року Болонської декларації про єдиний європейський простір освіти, однією зі стратегічних цілей якої є створення умов для конвергенції національних систем вищої освіти.

Активізацію діяльності щодо європеїзації вищої освіти СР можна прослідкувати щонайменше у двох напрямках: перший- це створення правових основ через ухвалення нормативних актів, другий - практичні дії з їх реалізації та інші ініціативи в освітньому процесі.

Базові нормативні рамки щодо поступового впровадження Болонського процесу були створені в 2002 р. Законом «Про вищі школи» і Постановою Міністерства освіти СР «Про кредитну систему навчання» (№614/2002).

Новий Закон «Про вищі школи», що вступив у дію 1 квітня 2002 року, врегулював широкий спектр питань щодо правового положення ВН3, їх фінансування та управління, навчальних програм і спеціальностей, акредитації, статусу викладачів і студентів, їх соціальної підтримки тощо.

У період діяльності другого уряду М. Дзурінди (2002-2006 рр.) відбувається безпосередня імплементація Болонського процесу. Відповідно до нормативних документів упроваджується кредитна система навчання на базі Європейської системи трансферу кредитів (ЕСТS), установлюються кваліфікаційні рівні, реструктуризується система навчальних спеціальностей щодо їх кількості та змісту тощо.

3 урахуванням міжнародної стандартної класифікації освіти ICSED97 в 2004 2005 pр. була структурована система педагогічних спеціальностей (табл. 1).

Система педагогічних спеціальностей [5].

Таблиця 1.

Навчальні спеціальності групи 1. Виховання і освіта

1.1.1. Навчання академічних предметів

1.1.2. Навчання професійних предметів і практичної підготовки

1.1.3. Навчання мистецько-виховних та виховних предметів

1.1.4. Педагогіка

1.1.5. Дошкільна та початкова педагогіка

1.1.6. Спеціальна педагогіка

1.1.7. Медична педагогіка

1.1.8. Логопедія

1.1.9. Андрагогіка

1.1.10. Професійна дидактика

Педагогічні спеціальності в новій системі навчальних спеціальностей розділено на три напрями 3 диференціацією переважаючих способів когнітивного, змістово- 
фізичного або психомоторного навчання студентів.

Поступово педагогічні спеціальності, навчальні програми 3 підготовки вчителів адаптуються до вимог суспільства та ринку праці. І як засвідчують реалії сьогодення Словаччини, потенціал у професії вчителя є. Ураховуючи, що нині у Словаччині функціонує 20 громадських, 3 державних і 13 приватних вищих шкіл, підготовку за педагогічними навчальними програмами чи додатковим педагогічним навчанням здійснює більше половини ВНЗ (табл. 2).

Таблиця 2.

Кількісне співвідношення ВНЗ Словаччини, що здійснюють підготовку вчителів [2, с. 40]

\begin{tabular}{|c|c|c|}
\hline Тип ВН3 & $\begin{array}{c}\text { Педагогічні навчальні програми } \\
\text { (спеціальності) }\end{array}$ & $\begin{array}{c}\text { Додаткове педагогічне } \\
\text { навчання }\end{array}$ \\
\hline Громадські & 11 & 16 \\
\hline Державні & 0 & 3 \\
\hline Приватні & 1 & 4 \\
\hline Загалом & 12 & 23 \\
\hline
\end{tabular}

Також важливим $є$ те, що держава орієнтується на нормативну підтримку статусу педагогічного працівника. У 2007 році урядом було прийнято «Концепцію професійного розвитку вчителів у кар'єрній системі» [1], що стало вихідною основою для ухвалення у 2009 р. Закону «Про педагогічних працівників...» [10]. Закон містить нововведення щодо правового статусу педагогів, їх кваліфікації, систематичного професійного розвитку, педагогічної практики, атестації, кар'єрних ступенів, соціального захисту тощо. Закон 2009 року став значною подією в системі педагогічної освіти, оскільки вперше за двадцятиліття розвитку після зміни соціальної системи професія педагога стала предметом регулювання окремого законодавчого акту.

У контексті інтеграції до європейського освітнього простору відбувається поглиблення інтернаціоналізації вищої освіти і науки, що сприяло розширенню багатосторонньої взаємодії словацьких ВНЗ, підвищенню їх конкурентоспроможності та відкритості, покращенню якості навчання та наукових досліджень. Словаччина долучилася до європейських програм у сфері освіти, науки та підготовки фахівців, що передбачають мобільність студентів та викладачів, партнерську участь ВНЗ у спільних проектах (Socrates, Leonardo da Vinci, Erasmus, Jean Monnet, Tempus).

Сутнісними характеристиками модернізації вищої педагогічної освіти в СР є: прагнення, зберігаючи національну специфіку, наблизити іiі до європейських стандартів; поряд 3 упливом фундаментальної загальнонаукової освіти поглибити професійно-педагогічну підготовку та практичну орієнтацію майбутніх учителів; посилити увагу до педагогічної освіти, підвищити її престижність.

Отже, упродовж кін. 1990-х - поч. 2000-х рр. у Словаччині відбулися значні зміни в системі вищої освіти, зорієнтовані на оновлення іiі структури та концептуально-нормативного забезпечення, модернізацію підготовки педагогічних фахівців у контексті входження до європейського освітнього простору. У перспективі вбачаємо доцільним подальший аналіз розвитку та функціонування словацької та української систем вищої педагогічної освіти крізь компаративну призму.

\section{Література}

1. Koncepcia profesijného rozvoja učitel'ov v kariérnom systéme / M. Černotová, L. Drga, B. Kasáčová [et al.] // Pedagogické rozhl'ady : odborno-metodický časopis. - Č. 3. 
(Roč. 15). - S. 3-26. 2. Krajčová N. Pregraduálna príprava učitel’ov - stav a očakávania / Nadežda Krajčová // Učitel' na ceste k profesionalite : recenzovaný zborník vedeckých prác / N. Krajčová, V. Šutáková eds. - Prešov: FHPV PU a Škola plus, s.r.o. - S. 37-45. 3. Národný program výchovy a vzdelávania v Slovenskej republike [Electronic Resource]. Mode of access : URL : http://www.noveskolstvo.sk/upload/pdf/npvv.pdf 4. Programové vyhlásenie vlády SR z 25. novembra 1998 [Electronic Resource]. - Bratislava : Úrad vlády SR, 1998. - Mode of access : URL : http://www.vlada.gov.sk/ 5. Sústava študijných odborov. 1.1. Učitel'stvo, vychovávatel'stvo a pedagogické vedy [Electronic Resource]. Mode of access : URL : http://www.akredkom.sk/index.pl?tmpl=odbory 6. Uznesenie vlády SR 685/2000 z 30. augusta 2000 k návrhu koncepcie d'alšieho rozvoja vysokého školstva na Slovensku pre 21. storočie [Electronic Resource]. - Mode of access: URL : http://www.vlada.gov.sk/uznesenia/2000/0830/u_0685_2000.html 7. Vyhláška Ministerstva školstva SR z 26. januára 1996 o d'alšom vzdelávaní pedagogických pracovníkov // Zbierka zákonov. - 1996. - Čiastka 16. - Č. 42. - S. 416-418. 8. Vyhláška Ministerstva školstva SR z 26. januára 1996 o odbornej a pedagogickej spôsobilosti pedagogických pracovníkov // Zbierka zákonov. - 1996. - Čiastka 16. - C̆. 41. - S. 398-415. 9. Vysokoškolské vzdelávanie učitel'ov : vývoj, analýza, perspektívy / B.Kosová [et al.]. - Banská Bystrica : Pedagogická fakulta Univerzity Mateja Bela, 2012. - 143 s. 10. Zákon č. 317/2009 z 24. júna 2009 o pedagogických zamestnancoch a odborných zamestnancoch a o zmene a doplnení niektorých zákonov // Zbierka zákonov. - Čiastka 113. - S. 2334-2361.

УДК $378.22+377.35+001$

Ірина Княжева

\section{ПРОБЛЕМА ПРОФЕСІЙНОЇ ПІДГОТОВКИ ВИКЛАДАЧІВ ВИЩОЇ ШКОЛИ ДО ПЕДАГОГІЧНОЇ ДІЯЛЬНОСТІ В УМОВАХ МАГІСТРАТУРИ В НАУКОВИХ ДОСЛІДЖЕННЯХ}

Княжева І. А.Проблема професійної підготовки викладачів вищої школи до педагогічної діяльності в умовах магістратури в наукових дослідженнях.

У статті проведено аналіз стану проблеми професійної підготовки викладачів вищої школи до педагогічної діяльності в умовах магістратури в теорії і практиці вищої освіти. Особливу увагу приділено висвітленню актуальних проблем професійної підготовки майбутніх фахівців у галузі дошкільної освіти, зокрема викладачів педагогічних дисциплін спеціальності «Дошкільна освіта».

Ключові слова: професійна підготовка, майбутні викладачі, магістратура, педагогічні дисципліни, вища школа.

Княжева И. А. Проблема профессиональной подготовки преподавателей высшей школы к педагогической деятельности в условиях магистратуры в научных исследованиях.

В статье проведен анализ проблемы профессиональной подготовки преподавателей высшей школы к педагогической деятельности в условиях магистратуры в теории и практике высшего образования. Особое внимание уделено освещению актуальных проблем профессиональной подготовки будущих специалистов в области дошкольного образования, в том числе преподавателей педагогических дисциплин специальности «Дошкольное образование».

Ключевые слова: профессиональная подготовка, будущие преподаватели, магистратура, педагогические дисциплины, высшая школа. 